\title{
PENGARUH PROFESIONALISME AUDITOR TERHADAP KUALITAS AUDIT DENGAN INTEGRITAS SEBAGAI VARIABEL MODERASI PADA KANTOR AKUNTAN PUBLIK KOTA MEDAN
}

\author{
Agus Tina ${ }^{1}$ \\ Universitas Muhammadiyah \\ Sumatera Utara \\ agustinat1983@gmail.com
}

\author{
Eka Nurmala Sari ${ }^{2}$ \\ Universitas Muhammadiyah \\ Sumatera Utara \\ ekanurmala@umsu.ac.id
}

\begin{abstract}
This study aims to determine, test and analyze empirically about the effect of professionalism to audit quality wich is moderated by integrity at public accountant firm in Medan. This study is quantitative study with associative approach. The objects of this research are the auditors who work in Public Accounting Firm in Medan. The sampling technique used in this research was stratified random sampling with a sample size of 63 respondents from a total population of 168 respondents. The data collection technique was carried out by distributing questionnaires. While the data analysis technique is using by structural equation model partial least square (SEM-PLS) which is processed using Smart PLS statistical software. The results showed that the Professionalism has no effect on audit quality at Public Accountant Firm in Medan. But integrity could moderated the effect of professionalism to audit quality at Public Accountant Firm in Medan.
\end{abstract}

Keywords: Professionalism, Integrity, Audit Quality.

\begin{abstract}
Abstrak
Penelitian ini bertujuan untuk mengetahui, menguji dan menganalisa secara empiris mengenai pengaruh profesionalisme auditor terhadap kualitas audit yang dimoderasi oleh integritas Pada Kantor Akuntan Publik di Kota Medan. Jenis penelitian ini adalah penelitian kuantitatif dengan pendekatan asosiatif. Objek pada penelitian ini adalah auditor yang bekerja pada Kantor Akuntan Publik di Kota Medan. Teknik Sampling yang digunakan dalam penelitian ini adalah stratified random sampling dengan jumlah sampel sebanyak 63 responden dari total populasi sebanyak 168 responden. Teknik pengumpulan data dilakukan dengan melalui pendistribusian kuisioner. Sedangkan Teknik analisis data adalah menggunakan structural equation model partial least square (SEM-PLS) yang diproses menggunakan perangkat lunak statistik Smart PLS. Hasil dari penelitian ini menunjukkan bahwa Profesionalisme auditor tidak berpengaruh terhadap kualitas audit Pada Kantor Akuntan Publik di Kota Medan. Sedangkan integritas mampu memoderasi pengaruh profesionalisme auditor terhadap kualitas audit pada Kantor Akuntan Publik di Kota Medan.
\end{abstract}




\section{Kata kunci: Profesionalisme, Integritas, Kualitas Audit.}

\section{PENDAHULUAN}

Profesi akuntan publik merupakan profesi kepercayaan masyarakat. Profesi akuntan publik bertanggung jawab untuk menaikkan tingkat keandalan laporan keuangan perusahaan, sehingga masyarakat memperoleh informasi keuangan yang andal sebagai dasar pengambilan keputusan (Mulyadi, 2002). Dalam melaksanakan tugas auditnya agar dapat menghasilkan audit yang berkualitas, auditor harus berpedoman pada standar audit yang ditetapkan oleh Institute Akuntan Publik Indonesia (IAPI), yakni standar umum, standar pekerjaan lapangan dan standar pelaporan. Dimana standar umum merupakan cerminan kualitas pribadi yang harus dimiliki oleh seorang auditor yang diwajibkan menggunakan kemahiran profesionalnya dengan cermat dan seksama. Standar ini mengharuskan auditor untuk bertanggung jawab secara cermat dan seksama dalam menjalankan tugasnya sebagai seorang auditor. Sedangkan standar pekerjaan lapangan dan standar pelaporan yang mengatur auditor dalam hal pengumpulan data dan kegiatan lainnya yang dilaksanakan selama melakukan audit serta mewajibkan auditor untuk menyusun laporan keuangan yang diauditnya secara keseluruhan (Tjun et al., 2012).

Berbagai temuan kasus terhadap laporan keuangan yang dihasilkan akuntan publik pada umumnya telah menimbulkan persepsi negatif pada masyarakat dan pengguna jasa layanan akuntan publik, hal ini dapat ditemukan dari berbagai kasus yang terjadi diantaranya adalah kasus PT. Jui Shin Indonesia yang melibatkan KAP Dra. Meilina Pangaribuan, M.M.(IAPI, 2019). Kasus manipulasi Laporan Keuangan PT. Garuda Indonesia (Persero) Tbk yang melibatkan (KAP) Tanubrata Sutanto Fahmi Bambang \& Rekan (Member of BDO Internasional) (Pratiwi, 2019). Kasus SNP Finance yang melibatkan KAP Marlinna Syamsul dan KAP Satrio Bing Eny (Widyastuti, 2018). Kasus PT Asuransi Jiwasraya (Persero) yang melibatkan KAP Soejatna, Mulyana, dan rekan (2006-2012); KAP Hartanto, Sidik, dan Rekan (2010-2013); PricewaterhouseCoopers (PwC) (2016-2017) (Makki, 2020). Dengan maraknya skandal laporan keuangan yang terjadi pada akuntan publik di Indonesia, memberikan dampak besar kepercayaan publik terhadap profesi akuntan publik. Dan yang menjadi pertanyaan besar masyarakat adalah mengapa justru kasus-kasus tersebut melibatkan profesi akuntan publik, di mana seharusnya mereka sebagai pihak ketiga yang independen yang memberikan jaminan atas relevansi dan keandalan laporan keuangan, dikarenakan profesi 
tersebut memiliki peran penting dalam memberikan informasi yang dapat dipercaya dan diandalkan oleh pihak lain yang berkepentingan terhadap laporan keuangan.

Untuk mencegah terjadinya kasus skandal terhadap laporan keuangan, maka auditor harus meningkatkan kualitas auditnya dengan cara mempertahankan kepercayaan, akuntabilitas dan menyelesaikan pekerjaannya sesuai dengan standar audit yang telah ditetapkan. Auditor diharapkan mempunyai profesionalisme yang tinggi dalam melaksanakan tanggung jawabnya. Menurut Arens et al., (2010, hal 105) profesionalisme adalah suatu tanggung jawab yang dibebankan kepadanya dan lebih dari sekedar dari memenuhi tanggung jawab yang dibebankan kepadanya dan lebih dari sekedar memenuhi Undang-Undang dan peraturan masyarakat. Profesionalisme merupakan sikap bertanggungjawab terhadap apa yang telah ditugaskan kepadanya. Sikap profesionalisme akan mengambil keputusan berdasarkan pertimbangan yang dimilikinya yaitu berdasarkan yang pertama pengabdian pada profesi, auditor yang mengabdi kepada profesinya akan melakukan totalitas kerja dimana dengan totalitas ini dia akan lebih hatihati dan bijaksana dalam melakukan audit sehingga dapat menghasilkan audit yang berkualitas (Agusti et al., 2013). Dalam standar umum ketiga SPAP ( Ikatan Akuntan Indonesia, 2001) menyatakan bahwa "Dalam pelaksanaan audit dan penyusunan laporannya, auditor wajib menggunakan kemahiran profesionalnya dengan cermat dan saksama". Standar ini mengharuskan auditor untuk bertanggung jawab secara cermat dan seksama dalam menjalankan tugasnya sebagai seorang auditor.

Dalam hal ini, fenomena kualitas audit tidak serta merta hanya dipengaruhi oleh profesionalisme. Integritas seorang auditor diduga dapat memperlemah atau memperkuat pengaruh profesionalisme auditor terhadap kualitas audit. Integritas berarti bahwa seseorang bertindak sesuai dengan kata hatinya, dalam situasi seperti apapun (Arens et al., 2010). Integritas merupakan suatu elemen karakter yang mendasari timbulnya pengakuan profesional. Integritas merupakan kualitas yang mendasari kepercayaan publik dan merupakan patokan (benchmark) bagi anggota dalam menguji semua keputusan yang diambilnya (Mulyadi, 2013). Pentingnya integritas berasal dari ide bahwa profesi adalah "panggilan" dan membutuhkan profesional untuk fokus pada gagasan bahwa mereka melakukan pelayanan publik. Integritas mempertahankan standar prestasi yang tinggi yang berarti memiliki kecerdasan, pendidikan, dan pelatihan untuk dapat nilai tambah melalui kinerja (Pitaloka dan Widanaputra, 2016). Semakin tinggi tingkat 
integritas yang dimiliki oleh seorang auditor maka akan semakin meningkatkan pengaruh profesionalisme terhadap kualitas audit.

Penelitian mengenai pengaruh profesionalisme auditor terhadap kualitas audit yang dimoderasi oleh integritas telah dilakukan oleh beberapa peneliti terdahulu diantaranya Alfasani (2017); Ermayanthi dan Rasmini (2016); B. Siahaan dan Simanjuntak (2017); Agusti et al., (2013); Ningrum dan Budiartha (2017); Susilo dan Widyastuti (2015) yang menyatakan bahwa profesionalisme auditor berpengaruh terhadap kualitas audit yang dimoderasi oleh integritas. Sedangkan penelitian yang dilakukan oleh Harsanty dan Whetyningty (2014); Wirama dan Mimba (2016); Wijaya (2016); Manalu Stefany dan Fietoria (2016) menyatakan bahwa integritas tidak memoderasi pengaruh profesionalisme auditor terhadap kualitas audit.

Berdasarkan paparan latar belakang masalah yang telah diuraikan dan beberapa hasil penelitian sebelumnya yang menunjukkan hasil yang berbeda-beda, peneliti tertarik melakukan penelitian dengan judul "Pengaruh Profesionalisme Auditor terhadap Kualitas Audit dengan Integritas sebagai Variabel Moderasi pada Kantor Akuntan Publik Kota Medan".

Adapun tujuan Penelitian ini adalah untuk menguji dan menganalisis: (1) pengaruh profesionalisme auditor terhadap kualitas audit pada Kantor Akuntan Publik Kota Medan, (2) pengaruh profesionalisme auditor terhadap kualitas audit yang dimoderasi oleh integritas pada Kantor Akuntan Publik Kota Medan.

\section{KERANGKA PEMIKIRAN DAN PENGEMBANGAN HIPOTESIS}

\subsection{Kerangka Pemikiran}

\section{a. Pengaruh Profesionalisme Auditor Terhadap Kualitas Audit}

Profesionalisme merupakan salah satu syarat yang harus dipenuhi dan dimiliki oleh seorang auditor dimana hal ini akan berdampak kepada sikap serta keteguhan didalam menjalankan profesi sebagai auditor independen yang pada akhirnya akan menentukan kualitas audit yang dihasilkan (Yendrawati, 2006). Profesionalisme bisa dilihat dari perilaku karena perilaku profesional merupakan cerminan dari sikap profesionalisme. Perilaku tersebut dapat dilihat dari pengabdian pada profesi, kewajiban sosial, kemandirian, keyakinan terhadap peraturan profesi, dan hubungan dengan sesama 
profesi. Untuk itu, penekanan pada tingkat profesionalisme lebih didasarkan pada sikap seseorang dalam menyingkapi berbagai masalah sehubungan dengan pekerjaan yang ditanganinya. Hal ini menjadikan kualitas audit yang dihasilkan oleh auditor yang profesional akan berkualitas baik. Hal ini sejalan dengan penelitian yang dilakukan oleh Alfasani (2017); Ermayanthi dan Rasmini (2016); B. Siahaan dan Simanjuntak (2017); Agusti et al., (2013); Ningrum dan Budiartha (2017); Susilo dan Widyastuti (2015) yang menyatakan bahwa profesionalisme auditor berpengaruh terhadap kualitas audit. Yang artinya semakin tinggi sikap profesionalisme yang dimiliki seorang auditor, maka akan semakin meningkatkan kualitas audit yang dihasilkan.

H1. Profesionalisme Auditor Berpengaruh Terhadap Kualitas Audit

\section{b. Pengaruh Profesionalisme Auditor terhadap Kualitas Audit Yang Dimoderasi oleh Integritas}

Integritas adalah suatu elemen karakter yang mendasari timbulnya suatu pengakuan profesional. Integritas merupakan kualitas yang mendasari kepercayaan publik dan merupakan patokan bagi anggota dalam menguji keputusan-keputusan yang diambil auditor tersebut (Mulyadi, 2013). Profesionalisme merupakan salah satu syarat yang harus dipenuhi dan dimiliki oleh seorang auditor dimana hal ini akan berdampak kepada sikap serta keteguhan didalam menjalankan profesi sebagai auditor independen yang pada akhirnya akan menentukan kualitas audit yang dihasilkan (Yendrawati, 2006). Dengan integritas yang tinggi dalam menjalankan tanggung jawabnya secara profesional, maka kualitas audit yang dihasilkan akan semakin tinggi. Hal ini sejalan dengan penelitian yang dilakukan oleh Alfasani (2017); Ermayanthi dan Rasmini (2016); Ningrum dan Budiartha (2017) yang menyatakan bahwa integritas mampu memoderasi pengaruh profesioalisme auditor terhadap kualitas audit.

H2. Integritas Memoderasi Pengaruh Profesionalisme Auditor Terhadap Kualitas Audit

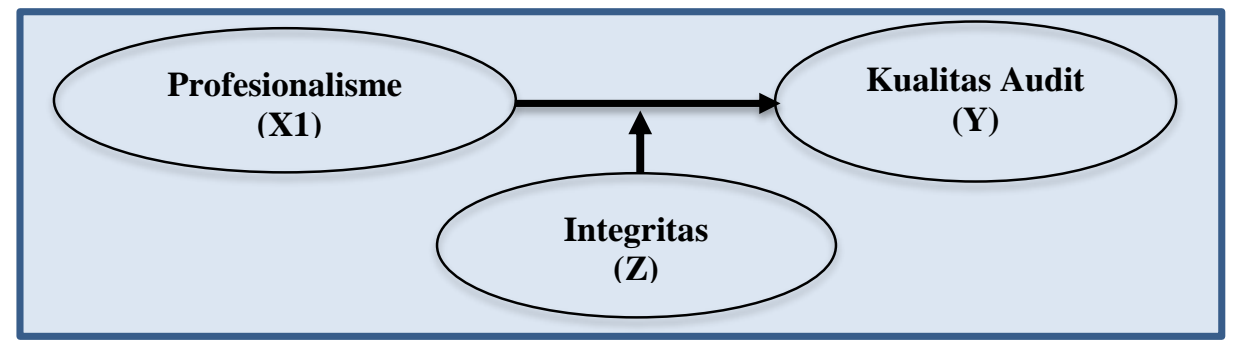

Gambar 1. Hubungan Antar Variabel dalam Penelitian 
Dari berbagai uraian di atas, keterkaitan antar variabel dalam penelitian ini secara ringkas dapat dilihat melalui kerangka konseptual yang ditampilkan pada gambar 1 .

\subsection{Pengembangan Hipotesis}

Berdasarkan kerangka konsep tersebut di atas, maka hipotesis yang diajukan dalam penelitian ini adalah :

a. Profesionalisme auditor berpengaruh terhadap kualitas audit pada Kantor Akuntan Publik Kota Medan.

b. Integritas memoderasi pengaruh profesionalisme auditor terhadap kualitas audit pada Kantor Akuntan Publik Kota Medan.

\section{METODE PENELITIAN}

\subsection{Jenis Penelitian}

Jenis penelitian dalam penelitian ini termasuk penelitian asosiatif. Populasi dalam penelitian adalah seluruh auditor yang bekerja pada KAP Kota Medan yang terdaftar dalam IAPI tahun 2019 yaitu sebanyak 168 responden. Penelitian ini menggunakan metode stratified random sampling. Penentuan jumlah sampel dalam penelitian ini dilakukan dengan cara perhitungan statistik dengan menggunakan Rumus Slovin dengan tingkat presisi yang ditetapkan dalam penentuan sampel adalah $10 \%$. Rumus Slovin yang digunakan adalah sebagai berikut :

$$
n=\frac{N}{1+N e^{2}}
$$

$$
\begin{aligned}
& \text { Keterangan: } \\
& \mathrm{n}=\text { jumlah sampel } \\
& \mathrm{N}=\text { jumlah populasi } \\
& \mathrm{e}=\text { batas toleransi kesalahan }(10 \%)
\end{aligned}
$$

Berdasarkan Rumus Slovin di atas, maka besarnya penarikan jumlah sampel penelitian adalah :

$$
\begin{aligned}
\mathrm{n} & =\frac{N}{1+N(e)^{2}} \\
\mathrm{n} & =\frac{168}{1+168(10 \%)^{2}} \\
\mathrm{n} & =\frac{168}{2,68} \\
\mathrm{n} & =62,686 \text { dibulatkan menjadi } 63 \text { responden }
\end{aligned}
$$


Berdasarkan Rumus Slovin tersebut, maka besarnya penarikan jumlah sampel penelitian adalah 63 responden.

\subsection{Definisi Operasional Variabel Penelitian}

\section{Tabel 1}

\section{Definisi Operasional Variabel Penelitian}

\begin{tabular}{|c|c|c|c|c|c|}
\hline $\begin{array}{c}\text { No } \\
\text {. }\end{array}$ & $\begin{array}{c}\text { Variabel } \\
\text { Penelitian }\end{array}$ & Definisi Operasional & Indikator & Skala & No. Butir \\
\hline 1. & $\begin{array}{l}\text { Profesionalisme } \\
\text { (X) }\end{array}$ & $\begin{array}{l}\text { Profesionalisme yaitu, sikap, } \\
\text { perilaku serta keterampilan } \\
\text { tinggi seorang auditor dalam } \\
\text { menjalankan profesinya dengan } \\
\text { kesungguhan dan tanggung } \\
\text { jawab agar mencapai kinerja } \\
\text { tugas sebagaimana yang diatur } \\
\text { oleh organisasi profesi. }\end{array}$ & $\begin{array}{l}\text { 1. Pengabdian pada profesi } \\
\text { 2. Kewajiban Sosial } \\
\text { 3. Kemandirian } \\
\text { 4. Keyakinan terhadap peraturan } \\
\text { profesi } \\
\text { 5. Hubungan dengan sesama } \\
\text { profesi }\end{array}$ & Ordinal & \begin{tabular}{|l}
1 s/d 2 \\
3 s/d 4 \\
5 s/d 6 \\
7 s/d 8 \\
9 s/d 10
\end{tabular} \\
\hline 2. & Integritas (Z) & $\begin{array}{l}\text { Integritas berarti suatu karakter } \\
\text { yang mencerminkan kepribadian } \\
\text { yang dilandasi oleh unsur } \\
\text { kejujuran, keberanian, bijaksana } \\
\text { dan tanggung jawab dalam } \\
\text { membangun kepercayaan guna } \\
\text { memberi dasar dalam } \\
\text { pengambilan keputusan yang } \\
\text { dapat diandalkan. }\end{array}$ & $\begin{array}{ll}\text { 1. } & \text { Kejujuran auditor } \\
\text { 2. } & \text { Keberanian auditor } \\
\text { 3. } & \text { Sikap bijaksana auditor } \\
\text { 4. } & \text { Tanggung Jawab Auditor }\end{array}$ & Ordinal & $\begin{array}{l}1 \text { s/d } 3 \\
4 \text { s/d } 6 \\
7 \text { s/d } 8 \\
9 \text { s/d } 10\end{array}$ \\
\hline 3. & $\begin{array}{l}\text { Kualitas Audit } \\
\text { (Y) }\end{array}$ & $\begin{array}{l}\text { Kualitas audit adalah segala } \\
\text { kemungkinan dimana auditor } \\
\text { pada saat mengaudit laporan } \\
\text { keuangan klien mampu } \\
\text { menemukan dan melaporkan } \\
\text { pelanggaran atau salah saji } \\
\text { material dalam laporan keuangan } \\
\text { auditan, dimana dalam } \\
\text { melaksanakan tugasnya tersebut } \\
\text { auditor berpedoman pada standar } \\
\text { auditing dan kode etik akuntan } \\
\text { publik yang relevan. }\end{array}$ & $\begin{array}{l}\text { 1. Kesesuaian pemeriksaan } \\
\text { dengan stándar audit } \\
\text { 2. Kualitas laporan hasil audit }\end{array}$ & Ordinal & $\begin{array}{l}1 \text { s/d } 6 \\
7 \text { s/d } 10\end{array}$ \\
\hline
\end{tabular}

Sumber : Data diolah, 2020

\subsection{Uji Instrumen Penelitian}

Sebelum melakukan pengumpulan data, analisis data dan uji hipotesis terdapat beberapa syarat yang harus dipenuhi, yaitu melakukan uji instrumen penelitian. Dalam penelitian ini pengujian instrumen menggunakan evaluasi model pengukuran (outer model), berupa uji validitas dan uji reliabilitas. Menurut Abdillah et al., (2015, hal 194) Uji validitas dilakukan untuk mengetahui kemampuan instrumen dalam mengukur apa 
yang seharusnya diukur. Terdapat 2 uji validitas dalam penelitian ini yaitu uji validitas konvergen dan uji validitas diskriminan.

\section{Convergent Validity}

Rule of thumb yang digunakan dalam uji validitas konvergen adalah nilai loading factor > 0,5 serta nilai AVE > 0,5 (Ghozali \& Latan, 2015). Hasil AVE disajikan pada Tabel 2 dan hasil outer loading pada Tabel 2 sebagai berikut :

\section{Tabel 2}

\section{Hasil AVE (Average Variant Extracted)}

\begin{tabular}{|c|c|c|}
\hline Variabel / Konstruk & AVE & Hasil Uji \\
\hline Profesionalisme (X) & 0,689 & Valid \\
\hline Integritas (Z) & 0,740 & Valid \\
\hline Kualitas Audit (Y) & 0,641 & Valid \\
\hline
\end{tabular}

Sumber : Output Smart PLS

Berdasarkan tabel 2, diketahui bahwa nilai AVE setiap variabel adalah lebih besar dari 0,5. Sehingga dapat disimpulkan bahwa variabel atau konstruk yang digunakan dalam penelitian adalah valid.

Tabel 3

Hasil Outer Loading

\begin{tabular}{|c|c|c|c|c|c|c|c|}
\hline No. & Butir Pernyataan & $\mathbf{X 1}$ & $\mathrm{X} 2$ & $\mathbf{X 3}$ & $\mathbf{Z}$ & $\mathbf{Y}$ & Hasil Uji \\
\hline \multicolumn{8}{|c|}{ Profesionalisme (X2) } \\
\hline 1. & PP1 & & 0,873 & & & & Valid \\
\hline 2. & PP2 & & 0,836 & & & & Valid \\
\hline 3. & KS1 & & 0,921 & & & & Valid \\
\hline 4. & KS2 & & 0,830 & & & & Valid \\
\hline 5. & KN1 & & 0,879 & & & & Valid \\
\hline 5. & KN2 & & 0,832 & & & & Valid \\
\hline 6. & KPP1 & & 0,880 & & & & Valid \\
\hline 7. & KPP2 & & 0,801 & & & & Valid \\
\hline 8. & HSP1 & & 0,852 & & & & Valid \\
\hline 9. & HSP2 & & 0,530 & & & & Valid \\
\hline \multicolumn{8}{|c|}{ Integritas (Z) } \\
\hline 1. & KJA1 & & & & 0,851 & & Valid \\
\hline 2. & KJA2 & & & & 0,856 & & Valid \\
\hline 3. & KJA3 & & & & 0,928 & & Valid \\
\hline $4 .$. & KBA1 & & & & 0,816 & & Valid \\
\hline 5. & KBA2 & & & & 0,898 & & Valid \\
\hline 6. & KBA3 & & & & 0,849 & & Valid \\
\hline
\end{tabular}




\begin{tabular}{|l|l|c|c|c|c|c|c|}
\hline No. & \multicolumn{1}{|c|}{ Butir Pernyataan } & X1 & X2 & X3 & Z & Y & Hasil Uji \\
\hline 7. & SBA1 & & & & 0,851 & & Valid \\
\hline 8 & SBA2 & & & & 0,825 & & Valid \\
\hline 9. & SBA3 & & & & 0,863 & & Valid \\
\hline Kualitas Audit (Y) & & & & & 0,737 & Valid \\
\hline 1. & SA1 & & & & & 0,818 & Valid \\
\hline 2. & SA2 & & & & & 0,624 & Valid \\
\hline 3. & SA3 & & & & & 0,921 & Valid \\
\hline 4. & SA4 & & & & & 0,805 & Valid \\
\hline 5. & SA5 & & & & & 0,846 & Valid \\
\hline 6. & SA6 & & & & & 0,845 & Valid \\
\hline 7. & HA1 & & & & & 0,708 & Valid \\
\hline 8. & HA2 & & & & & 0,853 & Valid \\
\hline 9. & HA3 & & & & & 0,809 & Valid \\
\hline 10. & HA4
\end{tabular}

Sumber : Output Smart PLS

Berdasarkan tabel 3 di atas, diketahui bahwa nilai outer loading pada setiap indikator adalah lebih dari 0,5 . Sehingga dapat disimpulkan bahwa variabel dan indikator yang digunakan dalam penelitian adalah valid.

\section{Discriminant Validity}

Validitas Diskriminan berhubungan dengan prinsip bahwa pengukur-pengukur (manifest variable) konstruk yang berbeda seharusnya tidak berkorelasi tinggi, validitas diskriminan dinilai berdasarkan dinilai berdasarkan cross loading. Rule of thumb yang digunakan dalam uji validitas diskriminan adalah nilai cross loading lebih besar dari 0,7. Jika korelasi konstruk dengan item pengukuran lebih besar dari pada ukuran konstruk lainnya, maka menunjukkan ukuran blok mereka lebih baik dibandingkan dengan blok lainnya (Ghozali \& Latan, 2015). Hasil uji validitas diskriminan disajikan pada Tabel 4 sebagai berikut :

Tabel 4.

Hasil Cross Loading

\begin{tabular}{|c|c|c|c|c|c|c|c|}
\hline No & Butir Pernyataan & $\mathrm{X} 1$ & $\mathrm{X} 2$ & X3 & $\mathbf{Z}$ & $\mathbf{Y}$ & Hasil Uji \\
\hline \multicolumn{8}{|c|}{ Profesionalisme (X) } \\
\hline 1. & PP1 & 0,023 & 0,873 & 0,781 & 0,555 & 0,126 & Valid \\
\hline 2. & PP2 & 0,286 & $\mathbf{0 , 8 3 6}$ & 0,773 & 0,594 & 0,045 & Valid \\
\hline 3. & KS1 & 0,157 & $\mathbf{0 , 9 2 1}$ & 0,860 & 0,509 & 0,184 & Valid \\
\hline 4. & KS2 & 0,090 & $\mathbf{0 , 8 3 0}$ & 0,750 & 0,683 & 0,154 & Valid \\
\hline 5. & KN1 & 0,193 & $\mathbf{0 , 8 7 9}$ & 0,812 & 0,583 & 0,154 & Valid \\
\hline 6. & KN2 & 0,204 & $\mathbf{0 , 8 3 2}$ & 0,774 & 0,510 & 0,098 & Valid \\
\hline 7. & KPP1 & 0,011 & $\mathbf{0 , 8 8 0}$ & 0,790 & 0,655 & 0,214 & Valid \\
\hline
\end{tabular}




\begin{tabular}{|l|l|c|c|c|c|c|c|}
\hline No & Butir Pernyataan & X1 & X2 & X3 & Z & Y & Hasil Uji \\
\hline 8. & KPP2 & 0,309 & $\mathbf{0 , 8 0 1}$ & 0,739 & 0,504 & 0,056 & Valid \\
\hline 9. & HSP1 & 0,142 & $\mathbf{0 , 8 5 2}$ & 0,800 & 0,390 & 0,062 & Valid \\
\hline 10. & HSP2 & 0,290 & $\mathbf{0 , 5 3 0}$ & 0,462 & 0,439 & 0,058 & Valid \\
\hline Integritas $(\mathbf{Z})$ & 0,038 & 0,596 & 0,500 & $\mathbf{0 , 8 5 1}$ & 0,111 & Valid \\
\hline 1. & KJA1 & 0,157 & 0,595 & 0,520 & $\mathbf{0 , 8 5 6}$ & 0,137 & Valid \\
\hline 2. & KJA2 & 0,017 & 0,592 & 0,516 & $\mathbf{0 , 9 2 8}$ & 0,197 & Valid \\
\hline 3. & KJA3 & 0,213 & 0,623 & 0,537 & $\mathbf{0 , 8 1 6}$ & 0,178 & Valid \\
\hline $4 .$. & KBA1 & 0,043 & 0,621 & 0,543 & $\mathbf{0 , 8 9 8}$ & 0,202 & Valid \\
\hline 5. & KBA2 & 0,050 & 0,396 & 0,320 & $\mathbf{0 , 8 4 9}$ & 0,195 & Valid \\
\hline 6. & KBA3 & 0,112 & 0,647 & 0,551 & $\mathbf{0 , 8 5 1}$ & 0,196 & Valid \\
\hline 7. & SBA1 & 0,157 & 0,539 & 0,465 & $\mathbf{0 , 8 2 5}$ & 0,105 & Valid \\
\hline 8 & SBA2 & 0,127 & 0,577 & 0,497 & $\mathbf{0 , 8 6 3}$ & 0,066 & Valid \\
\hline 9. & SBA3 & 0,060 & 0,270 & 0,277 & 0,251 & $\mathbf{0 , 7 3 7}$ & Valid \\
\hline Kualitas Audit (Y) & SA1 & 0,214 & 0,168 & 0,188 & 0,013 & $\mathbf{0 , 8 1 8}$ & Valid \\
\hline 1. & 0,063 & 0,011 & 0,015 & 0,001 & $\mathbf{0 , 6 2 4}$ & Valid \\
\hline 2. & SA2 & 0,388 & 0,063 & 0,062 & 0,119 & $\mathbf{0 , 9 2 1}$ & Valid \\
\hline 3. & SA3 & 0,218 & 0,094 & 0,088 & 0,209 & $\mathbf{0 , 8 0 5}$ & Valid \\
\hline 4. & SA4 & 0,286 & 0,278 & 0,287 & 0,251 & $\mathbf{0 , 8 4 6}$ & Valid \\
\hline 5. & SA5 & 0,264 & 0,019 & 0,008 & 0,109 & $\mathbf{0 , 8 4 5}$ & Valid \\
\hline 6. & SA6 & 0,160 & 0,274 & 0,249 & 0,363 & $\mathbf{0 , 7 0 8}$ & Valid \\
\hline 7. & HA1 & 0,255 & 0,012 & 0,007 & 0,007 & $\mathbf{0 , 8 5 3}$ & Valid \\
\hline 8. & HA2 & 0,349 & 0,007 & 0,012 & 0,142 & $\mathbf{0 , 8 0 9}$ & Valid \\
\hline 9. & HA3 & Sur &
\end{tabular}

Sumber : Output Smart PLS

Berdasarkan data pada tabel 4 di atas, dapat diketahui bahwa masing-masing indikator pada variabel penelitian memiliki nilai cross loading lebih tinggi pada variabel yang dibentuknya dibandingkan dengan nilai cross loading pada variabel lainnya. Berdasarkan hasil yang diperoleh tersebut, dapat dinyatakan bahwa indikator-indikator yang digunakan dalam penelitian ini telah memiliki discriminant validity yang baik dalam menyusun variabelnya masing-masing.

\section{Uji Reabilitas}

Reliabilitas menunjukkan akurasi, konsistensi, dan ketepatan suatu alat ukur dalam melakukan pengukuran. Uji reliabilitas dalam PLS dapat menggunakan dua metode yaitu cronbach's alpha dan composite reliability. Cronbach's alpha mengukur batas bawah nilai reliabilitas suatu konstruk sedangkan composite reliability mengukur nilai sesungguhnya reliabilitas suatu konstruk. Rule of thumb yang digunakan untuk nilai composite reliability lebih besar dari 0,7 serta nilai cronbach's alpha lebih besar dari 0,7. Dengan pengukuran tersebut apabila nilai yang dicapai adalah $>0,70$ maka dapat 
dikatakan bahwa konstruk tersebut memiliki reliabilitas yang tinggi. Hasil uji reabilitas kedua metode dapat dilihat pada tabel berikut ini :

\section{Tabel 5}

\section{Hasil Uji Reabilitas}

\begin{tabular}{|c|c|c|c|}
\hline Variabel / Konstruk & $\begin{array}{c}\text { Cronbach's } \\
\text { Alpha }\end{array}$ & $\begin{array}{c}\text { Composite } \\
\text { Reliability }\end{array}$ & Hasil Uji \\
\hline Profesionalisme (X) & 0,951 & 0,956 & Reliabel \\
\hline Integritas (Z) & 0,957 & 0,962 & Reliabel \\
\hline Kualitas Audit (Y) & 0,938 & 0,946 & Reliabel \\
\hline
\end{tabular}

Sumber : Output Smart PLS

Berdasarkan sajian data pada tabel 5 di atas, dapat diketahui bahwa masingmasing variabel penelitian memiliki nilai cronbach's alpha dan composite reliability > 0,7. Berdasarkan hasil yang diperoleh tersebut, dapat dinyatakan bahwa variabel yang digunakan dalam penelitian dinyatakan reliabel.

\subsection{Teknik Analisis Data}

Teknik analisis data yang digunakan dalam penelitian ini menggunakan statistik deskriptif dan analisis statistik dengan menggunakan partial least square - structural equestion model (PLS-SEM). Dalam metode Partial Least Square (PLS) teknik analisa yang dilakukan adalah melakukan uji model struktural (inner model). Analisis model struktural (inner model) dalam penelitian ini dilakukan dengan melihat (a) uji koefisien determinasi ( $r$-square); (b) uji effect size / f-square (F2); (c) uji Goodness Of Fit (GoF); dan (d) pengujian hipotesis.

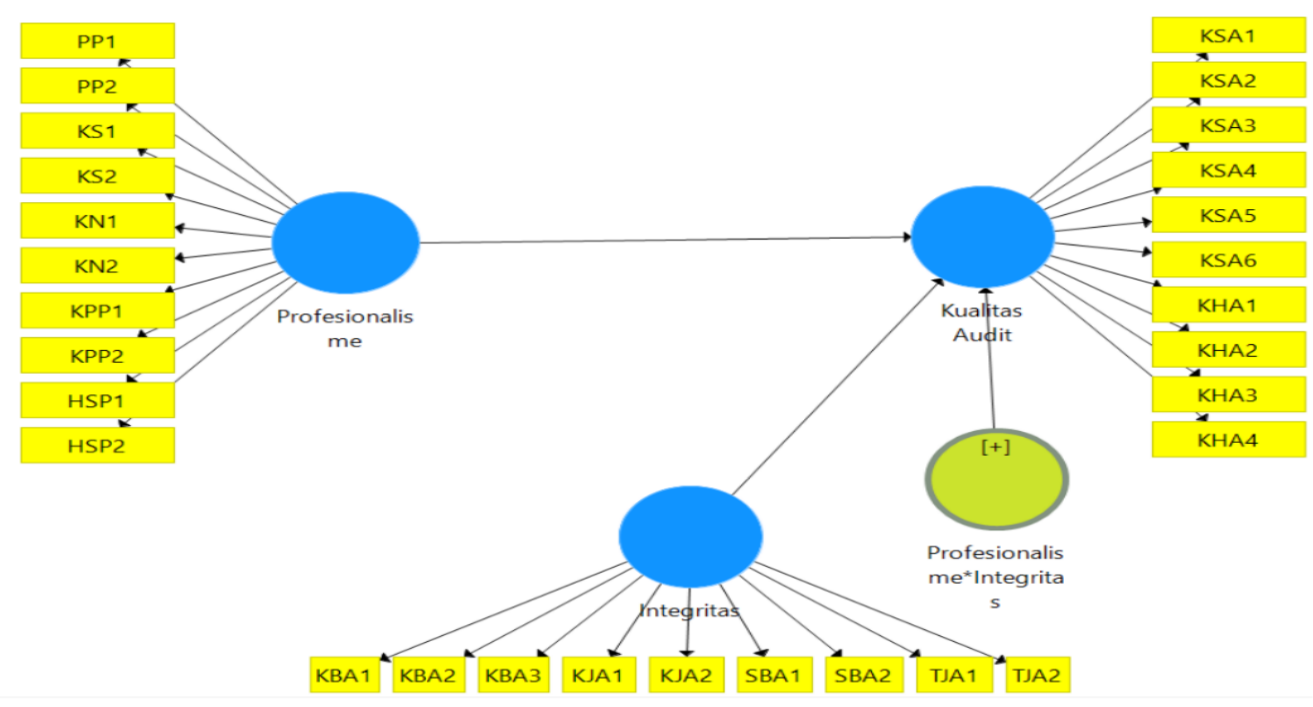

Gambar 2. Model Pengukuran dan Sutuktural 
Pengujian model pengukuran (outer model) dan model structural (inner model) dalam PLS dilakukan dengan bantuan software Smart PLS ver. 3 for Windows. Gambar 2 adalah gambar model pengukuran (outer model) dan model struktural (inner model) yang dibentuk dalam penelitian ini.

\section{HASIL PENELITIAN}

\subsection{Analisis Statistik Deskriptif}

Analisis statistik deskriptif untuk masing-masing variabel dapat dilihat pada tabel 6 berikut :

\section{Tabel 6}

\section{Statistik Deskriptif}

\begin{tabular}{|c|c|c|c|c|c|c|}
\hline \multicolumn{7}{|c|}{ Descriptive Statistics } \\
\hline & $\mathrm{N}$ & Minimum & Maximum & & & Std. Deviation \\
\hline & Statistic & Statistic & Statistic & Statistic & Std. Error & Statistic \\
\hline PROFESIONALISME & 63 & 35 & 49 & 42,10 &, 556 & 4,409 \\
\hline INTEGRITAS & 63 & 29 & 44 & 39,05 & ,484 & 3,841 \\
\hline KUALITAS AUDIT & 63 & 36 & 47 & 44,81 &, 375 & 2,978 \\
\hline Valid N (listwise) & 63 & & & & & \\
\hline
\end{tabular}

Sumber : Output SPSS

Dari tabel deskripsi statistik variabel penelitian di atas menunjukkan bahwa jumlah responden (N) adalah 63 orang. Masing- masing variabel memiliki nilai minimum, nilai maksimum, nilai rata-rata (mean) dan nilai standar deviasi yang bervariasi.

a. Profesioanlisme auditor $(\mathrm{X})$ diperoleh dengan menggunakan 10 butir pernyataan kepada 63 responden. Berdasarkan tabel 6 diketahui profesionalisme auditor memiliki nilai minimum sebesar 35 dan nilai maksimum sebesar 49. Nilai rata-rata profesionalisme auditor adalah 42,10. Nilai standar deviasi profesionalisme auditor adalah 4,409 yang berarti bahwa penyimpangan atas profesionalisme auditor sangat kecil. Dengan nilai standar deviasi yang lebih rendah dibandingkan dengan nilai rata-rata, maka nilai rata-rata dapat dijadikan representasi dari keseluruhan data.

b. Integritas auditor $(Z)$ diperoleh dengan menggunakan 10 butir pernyataan kepada 63 responden. Berdasarkan tabel 6 diketahui integritas auditor memiliki nilai minimum sebesar 29 dan nilai maksimum sebesar 44. Nilai rata-rata integritas responden 
adalah 39,05. Nilai standar deviasi integritas auditor adalah 3,841 yang berarti bahwa penyimpangan atas integritas auditor sangat kecil. Dengan nilai standar deviasi yang lebih rendah dibandingkan dengan nilai rata-rata, maka nilai rata-rata dapat dijadikan representasi dari keseluruhan data.

c. Kualitas audit (Y) diperoleh dengan menggunakan 10 butir pernyataan kepada 63 responden. Berdasarkan tabel 6 diketahui kualitas audit memiliki nilai minimum sebesar 36 dan nilai maksimum sebesar 47. Nilai rata-rata kualitas audit adalah 44,81. Nilai standar deviasi kualitas audit adalah 2,978 yang berarti bahwa penyimpangan atas kualitas audit sangat kecil. Dengan nilai standar deviasi yang lebih rendah dibandingkan dengan nilai rata-rata, maka nilai rata-rata dapat dijadikan representasi dari keseluruhan data.

\subsection{Uji Koefisien Determinasi (R-Square)}

$R$-square adalah ukuran proporsi variasi nilai yang dipengaruhi (endogen) yang dapat dijelaskan oleh variabel yang mempengaruhinya (eksogen), hal ini berguna untuk memprediksi apakah model adalah baik/buruk. Hasil $r$-square untuk variabel laten endogen sebesar 0,75 mengindikasikan bahwa model tersebut adalah substansial (baik); 0,50 mengindikasikan bahwa model tersebut adalah moderat (sedang) dan 0,25 mengindikasikan bahwa model tersebut adalah lemah (buruk) (Juliandi, 2018). Uji koefisien determinasi dapat dilihat pada tabel 7 berikut :

Tabel 7

\section{Uji Koefisien Determinasi}

\begin{tabular}{|c|c|c|c|c|}
\hline Variabel & Original Sample (O) & Sample Mean (M) & T Statistics & P Values \\
\hline Kualitas Audit (Y) & 0,600 & 0,636 & 6,564 & 0,000 \\
\hline
\end{tabular}

Sumber : Output Smart PLS

Berdasarkan tabel 7 di atas, diketahui nilai r-square sebesar 0,600 artinya bahwa kualitas audit (Y) dipengaruhi oleh profesionalisme (X) sebesar 60\%, sedangkan sisanya dipengaruhi oleh variabel lain diluar dari penelitian ini.

\subsection{Uji Effect Size}

F-Square adalah ukuran yang digunakan untuk menilai dampak relatif dari suatu variabel yang mempengaruhi (eksogen) terhadap variabel yang dipengaruhi (endogen). 
Kriteria penarikan kesimpulan adalah jika nilai $\mathrm{F}^{2}$ sebesar 0,02 maka terdapat efek yang kecil (lemah) dari variabel eksogen terhadap endogen, nilai $\mathrm{F}^{2}$ sebesar 0,15 maka terdapat efek yang moderat (sedang) dari variabel eksogen terhadap endogen, nilai $\mathrm{F}^{2}$ sebesar 0,35 maka terdapat efek yang besar (baik) dari variabel eksogem terhadap endogen (Juliandi, 2018). Uji $f$-square dapat dilihat pada tabel 8 berikut :

\section{Tabel 8}

\section{Hasil Effect Size}

\begin{tabular}{|l|c|c|}
\hline \multicolumn{1}{|c|}{ Variabel } & F-Square & Efek \\
\hline Profesionalise $\rightarrow$ Kualitas Audit & 0,032 & Kecil \\
\hline $\begin{array}{l}\text { Profesionalisme } \rightarrow \text { Kualitas Audit } \\
\text { Dimoderasi Integritas }\end{array}$ & 0,303 & Moderat \\
\hline
\end{tabular}

\section{Sumber : Output Smart PLS}

Berdasarkan tabel 8 di atas diketahui bahwa :

a. Pengaruh profesionalisme auditor $(\mathrm{X})$ terhadap kualitas audit $(\mathrm{Y})$ memiliki nilai $\mathrm{F}^{2}$ sebesar 0,032 mengindikasikan bahwa terdapat efek yang kecil (lemah).

b. Pengaruh profesionalisme auditor (X) terhadap kualitas audit (Y) yang dimoderasi oleh integritas $(\mathrm{Z})$ memiliki nilai $\mathrm{F}^{2}$ sebesar 0,303 mengindikasikan bahwa terdapat efek yang moderat (sedang).

\subsection{Uji Kebaikan Model (Goodness Of Fit)}

Untuk memvalidasi model struktural secara keseluruhan digunakan Goodness of Fit (GoF). GoF indeks merupakan ukuran tunggal untuk memvalidasi performa gabungan antara model pengukuran dan model struktural. Nilai GoF ini diperoleh GoF indeks merupakan ukuran tunggal untuk memvalidasi performa gabungan antara model pengukuran dan model struktural. Nilai GoF ini diperoleh dari akar kuadrat dari average communalities index dikalikan dengan nilai rata-rata $\mathrm{R}^{2}$ model. Nilai GoF terbentang antara 0 sd 1 dengan interpretasi nilai-nilai : 0.1 (Gof kecil), 0,25 (GoF moderate), dan 0.36 (GoF besar) (Hair, Hult, Ringle, \& Sarstedt, 2014). Rumus untuk menghitung nilai GoF adalah sebagai berikut :

$$
\begin{aligned}
\mathrm{GoF} & =\sqrt{\operatorname{Com}+R^{2}} \\
& =\sqrt{0,69+0,600} \\
& =\sqrt{1,29} \\
\mathrm{GoF} & =1,136
\end{aligned}
$$


Berdasarkan hasil perhitungan di atas, diperoleh nilai GoF sebesar 1,136. Dengan demikian, dari hasil tersebut maka model penelitian ini dapat dinyatakan memiliki goodness of fit yang kecil.

\subsection{Uji Hipotesis}

Dalam pengujian hipotesis dapat dilihat dari nilai probabilitas. Untuk menolak atau menerima hipotesis menggunakan probabilitas maka Ha diterima jika nilai probabilitas < 0,05 (Hair, et al., 2014). Pengujian model structural (inner model) dalam PLS dilakukan dengan bantuan software Smart PLS ver. 3 for Windows. Hasil uji hipotesis dapat dilihat pada tabel 9 berikut ini :

\section{Tabel 9}

\section{Hasil Path Coefficient}

\begin{tabular}{|l|c|c|c|}
\hline Variabel & $\begin{array}{c}\text { Original } \\
\text { Sample }\end{array}$ & T Statistics & P Values \\
\hline Profesionalisme $\rightarrow$ Kualitas Audit & 0,195 & 0,823 & 0,411 \\
\hline $\begin{array}{l}\text { Profesionalisme } \rightarrow \text { Kualitas Audit } \\
\text { Dimoderasi Integritas }\end{array}$ & 0,432 & 2,773 & 0,006 \\
\hline
\end{tabular}

Sumber : Output Smart PLS

\subsection{Pembahasan}

\section{a. Pengaruh Profesionalisme Auditor Terhadap Kualitas Audit}

Berdasarkan hasil uji hipotesis tabel 9, diketahui bahwa nilai $p$ value sebesar 0,411 > 0,05, sehingga Ha1 ditolak. Hal ini dapat diartikan bahwa variabel profesionalisme auditor tidak berpengaruh terhadap kualitas audit.

Dari hasil deskripsi responden ditemukan auditor sebanyak $68 \%$ responden yang pengalamannya masih dibawah 5 tahun dan 15,9\% responden yang menjabat sebagai junior auditor. Hal ini menunjukkan bahwa masih terdapat auditor yang tidak didukung dengan segenap pengetahuan, kemampuan dan pengalaman yang baik dan cukup, sehingga kualitas audit yang dihasilkan masih diragukan. Dalam penelitian ini, masih terdapat auditor yang tidak dapat menjalankan pekerjaannya secara profesional tanpa melihat imbalan yang sesuai. Auditor mengganggap pekerjaan yang dilakukannya hanya berdasarkan materi saja atau berdasarkan imbalan yang diterima. Seorang auditor dikatakan profesional jika ia mampu menjalankan pekerjaan secara profesional meskipun 
mendapatkan imbalan yang tidak sesuai. Tetapi pada kenyataannya, masih ditemukannya auditor yang masih belum menjalankan pekerjaannya secara profesional.

Berdasarkan Standar Profesi Akuntan Publik (SPAP) dalam (Ikatan Akuntan Indonesia, 2001) audit yang dilaksanakan auditor dikatakan berkualitas baik, jika memenuhi ketentuan atau standar pengauditan, yaitu standar umum, standar pelaksanaa pekerjaan lapangan dan standar pelaporan. Dalam hal ini standar yang berhubungan dengan profesinalisme terdapat pada Standar Umum point (c) yaitu dalam pelaksanaan audit dan penyusunan laporannya, auditor wajib menggunakan kemahiran profesionalnya dengan cermat dan saksama.

Hasil penelitian ini sejalan dengan penelitian yang dilakukan oleh Manalu Stefany dan Fietoria (2016); Futri dan Juliarsa (2014); Harsanty dan Whetyningty (2014); Wijaya (2016) yang menunjukkan bahwa profesionalisme auditor tidak berpengaruh signifikan terhadap kualitas audit. Untuk meningkatkan profesionalismenya auditor wajib menggunakan segenap pengetahuan, kemampuan dan pengalaman yang dimilikinya dalam melakukan audit dengan mengikuti pelatihan-pelatihan teknis mengenai audit sehingga berdampak pada peningkatan kualitas audit yang dihasilkan.

\section{b. Pengaruh Profesionalisme Auditor Terhadap Kualitas Audit Yang Dimoderasi Integritas}

Berdasarkan hasil uji hipotesis tabel 9, diketahui bahwa nilai $p$ value sebesar $0,006<0,05$, sehingga Ha2 diterima. Hal ini dapat diartikan bahwa variabel integritas auditor mampu memoderasi pengaruh profesionalisme auditor terhadap kualitas audit. Dengan kata lain, naik atau turunnya integritas seorang auditor memberikan pengaruh profesionalisme auditor terhadap kualitas audit yang artinya semakin tinggi integritas seorang auditor maka akan semakin memperkuat pengaruh profesionalisme auditor terhadap kualitas audit. Sebaliknya, semakin rendah integritas yang dimiliki seorang auditor, maka akan semakin memperlemah pengaruh profesionalisme auditor terhadap kualitas audit.

Hasil dalam penelitian ini menunjukkan bahwa integritas yang dimiliki auditor mampu meningkatkan sikap profesionalisme auditor dalam pemeriksaan audit yang dilakukannya. Auditor yang bersikap jujur dalam pelaksanaan tugas audit, akan selalu bersikap profesional karena auditor akan menganggap bahwa profesi yang dijalankannya merupakan kewajiban sosial dan pengabdian pada profesi. Auditor mengganggap bahwa 
profesi yang dijalankannya bukan hanya sekedar mencari materi saja atau imbalan yang sesuai, tetapi merupakan rasa tanggung jawab profesionalisme yang tinggi, sehingga auditor tidak dapat dengan mudah mendapat tekanan dari klien dalam melakukan audit laporan keuangan. Selain itu, auditor yang memiliki integritas yang tinggi akan mampu melaksanakan audit sesuai fakta dilapangan, serta mengganggap bahwa profesi auditor merupakan pekerjaan yang penting bagi masyarakat. Auditor akan memiliki keyakinan dalam menjalankan peraturan profesi serta mampu membina hubungan baik dengan sesama profesi. Hal ini yang menyebabkan auditor dapat melaksanakan profesinya dengan baik, sehingga kualitas laporan hasil audit yang dihasilkan juga akan semakin baik.

Penelitian ini sejalan dengan penelitian yang dilakukan oleh Alfasani (2017); Ermayanthi dan Rasmini (2016); Ningrum dan Budiartha (2017) yang menyatakan bahwa integritas mampu memoderasi pengaruh profesionalisme auditor terhadap kualitas audit. Seorang auditor harus mampu mempertahankan profesinya secara profesionalisme serta memiliki kejujujuran, keberanian, sikap yang bijaksana dan bertanggung jawab. Auditor yang mampu menjalankan profesinya secara profesionalisme dan didasarkan pada integritas yang tinggi, maka audit yang dihasilkan akan berkualitas.

\section{KESIMPULAN, IMPLIKASI DAN KETERBATASAN PENELITIAN}

\subsection{Kesimpulan}

Berdasarkan pada hasil penelitian serta pengujian hipotesis dapat ditarik kesimpulan bahwa Profesionalisme auditor tidak berpengaruh terhadap kualitas audit pada Kantor Akuntan Publik Kota Medan, tetapi Integritas memoderasi pengaruh profesionalisme auditor terhadap kualitas audit pada Kantor Akuntan Publik Kota Medan.

\subsection{Implikasi}

Dari hasil penelitian ini terdapat beberapa implikasi bahwa penelitian ini membuktikan profesionalisme auditor tidak berpengaruh terhadap kualitas audit. Namun dengan adanya integritas yang tinggi, maka integritas mampu memoderasi pengaruh profesionalisme auditor terhadap kualitas audit. Oleh karena itu, pemahaman terhadap profesionalisme auditor sebaiknya diterapkan dalam KAP (Kantor Akuntan Publik) dengan cara meningkatkan sikap profesionalismenya dalam melakukan proses 
pengauditan dengan menggunakan segenap pengetahuan, kemampuan dan pengalaman yang dimiliki melalui pelatihan-pelatihan teknis yang cukup mencakup aspek teknis maupun pendidikan umum, sehingga dapat meningkatkan kinerja auditor serta memberikan pelatihan dan pendidikan yang dapat menambah pengalaman dan pengetahuannya dalam profesi sebagai auditor, sehingga akan semakin baik kualitas audit yang dihasilkannya.

Pada Kantor Akuntan Publik, diharapkan dapat menjaga kualitas para auditornya di Kantor Akuntan Publik agar dapat menjunjung tinggi dan menjaga kualitas audit sehingga kredibilitas hasil audit di mata pengguna informasi laporan keuangan dapat dijaga.

\subsection{Keterbatasan Penelitian}

Sebagaimana suatu penelitian, penelitian ini juga memiliki keterbatasan yaitu sampel yang digunakan dalam penelitian tidak cukup representatif mewakili seluruh jumlah auditor yang ada di Kota Medan, dikarenakan pada saat melakukan penyebaran kuisioner, banyak kantor akuntan publik yang tutup untuk sementara dan hanya sebagian auditor yang berada di tempat karena dalam kondisi pandemi covid-19.

Dalam pengumpulan data, peneliti tidak bisa melakukan teknik wawancara atau observasi langsung terhadap auditor yang bekerja di kantor akuntan publik, dikarenakan masih dalam kondisi pandemi covid-19.

\subsection{Saran}

Untuk meningkatkan kualitas audit, seorang auditor dituntut untuk meningkatkan sikap profesionalismenya dalam melakukan proses pengauditan dengan menggunakan segenap pengetahuan, kemampuan dan pengalaman yang dimiliki melalui pelatihanpelatihan teknis yang cukup mencakup aspek teknis maupun pendidikan umum.

Disarankan untuk penelitian di masa mendatang dapat memperluas wilayah penelitian dan memperbayak jumlah populasi untuk mendapatkan hasil penelitian yang lebih baik, serta menggunakan metode wawancara atau observasi langsung kepada responden, sehingga jawaban responden dapat dikontrol sehingga tidak terjadi bias atau salah persepsi dari responden terhadap instrumen penelitian yang digunakan. 


\section{DAFTAR PUSTAKA}

Abdillah, W. dan Jogiyanto,H.M. 2009. Konsep dan Aplikasi PLS (Partial Least Square) Untuk Penelitian Empiris. Yogyakarta: Badan Penerbit Fakultas Ekonomi Dan Bisnis UGM.

Alfasani, R. 2017. "Faktor Yang Mempengaruhi Kualitas Audit Dengan Integritas Auditor Sebagai Moderasi". Jurnal Ilmu dan Riset Akuntansi (JIRA): 6(10).

Arens, A. A., Elder, R. J., dan Beasley, M. S. 2010. Jasa Audit dan Assurance: Pendekatan Terpadu (Adaptasi Indonesia). Edisi 12. Jakarta: Erlangga.

Agusti, Restu, dan Pertiwi, N.P. 2013. "Pengaruh Kompetensi auditor, Independensi, Profesionalisme Terhadap Kualitas Audit.” Jurnal Ekonomi 21(3): 1-13.

Ermayanthi, L. A. A., dan Rasmini, N. K. 2016. 'Integritas Sebagai Pemoderasi Pengaruh Profesionalisme Pada Kualitas Audit ". E-Jurnal Akuntansi: 1489-1515.

Futri, P. S., dan Juliarsa, G. 2014. "Pengaruh Independensi, Profesionalisme, Tingkat Pendidikan, Etika Profesi, Pengalaman, Dan Kepuasan Kerja Auditor Pada Kualitas Audit Kantor Akuntan Publik Di Bali". E-Jurnal Akuntansi Universitas Udayana: 444-461

Ghozali, I., dan Latan, H. 2015. Partial Least Square Konsep Teknik dan Aplikasi Menggunakan Program SmartPLS 3.0. Edisi 2. Semarang: Badan Penerbit Universitas Diponegoro.

Hair et al. 2014. A Primer on Partial Least Squares Structural Equation Modeling (PLS$S E M)$. Kindle Edition. United States of America: SAGE Publications, Inc.

Harsanty, P., dan Whetyningtyas, A. 2014. "Pengaruh Kompetensi, Independensi, Dan Profesionalisme Auditor Terhadap Kualitas Audit (Studi Empiris Pada Kantor Akuntan Publik Di Semarang)". Jurnal Sosial Budaya 7(1): 1-6.

Ikatan Akuntan Indonesia. 2001. Standar Profesional Akuntan Publik. Jakarta: Salemba Empat.

IAPI 2019. Direktori Kantor Akuntan Publik (KAP) Dan Akuntan Publik (AP).

Juliandi, A. 2018. Metodologi Penelitian Kuantitatif Untuk Ilmu-ilmu Bisnis (Cetakan Pertama). Medan: Percetakan M2000.

Manalu, S., Elisabeth dan Fietoria. 2016. "Pengaruh Profesionalisme ,Independensi, Dan Kompetensi Terhadap Kualitas Audit." Journal of Accounting and Business Studies 1(1): 1-19.

Mulyadi. 2002. Auditing. Edisi 6. Jakarta: Salemba Empat.

- 2013. Auditing. Buku 1. Edisi 6. Jakarta: Salemba Empat.

Makki, S. 2020. Sri Mulyani Bakal Hukum Akuntan Publik Yang Audit Jiwasraya. [Online]. Tersedia: https://www.cnnindonesia.com/ekonomi/2020011515433078-465608/sri mulyani-bakal-hukum-akuntan-publik-yang-audit-jiwasraya. (internet)

Ningrum, K. D., dan Budiartha, K. K. B. 2017. "Integritas Auditor Memoderasi Pengaruh Pengalaman Auditor, Kompetensi Auditor dan Profesionalisme Pada Kualitas Audit". E-Jurnal Akuntansi: 615-644. 
Pratiwi H.R. 2019. Kiruh Lapkeu BEI Minta Garuda Paparan Publik Luar Biasa. https://www.cnnindonesia.com/ekonomi/20190507170428-92-392776/kisruhlapkeu-bei-minta-garuda-paparan-publik-luar-biasa. (internet)

Pitaloka, Y. dan Widanaputra, A.A.G.P. 2016. "Integritas Auditor Sebagai Pemoderasi Pengaruh Kompetensi auditor Dan Independensi Pada Kualitas Audit.” E-Jurnal Akuntansi 16(2): 1574-1603.

Siahaan, Septoni, dan Simanjuntak. 2017. "Pengaruh Kompetensi , Independensi, Integritas Dan Profesionalisme Auditor Terhadap Kualitas Audit Dengan Etika Auditor Sebagai Variabel Moderasi (Studi Kasus Pada Kantor Akuntan Publik Di Kota Medan).” Jurnal Manajemen 8(2): 137-44.

Susilo, P.A. dan Widyastuti,T. 2015. "Integritas, Objektivitas, Profesionalime Auditor Dan Kualitas Audit Di Kantor Akuntan Publik Jakarta Selatan.” Jurnal Riset Akuntansi dan Perpajakan JRAP 2(1): 65-77.

Tjun et al. 2012. “The Magnetic Resonance Imaging Appearances in Kienböck's Disease." Jurnal Akuntansi Maranatha 4(1): 33-56.

Widyastuti, A. 2018. Kasus SNP Finance Kemenkeu Jatuhkan Sanksi Ke Deloitte Indonesia. $\quad$ https://bisnis.tempo.co/read/1130928/kasus-snp-finance-kemenkeujatuhkan-sanksi-ke-deloitte-indonesia. (internet)

Wirama, A. A. M. B., dan Mimba, N. P. S. H. 2016. "Kemampuan Integritas Memoderasi Pengaruh Independensi, Profesionalisme, Time Budget Pressure Pada Kualitas Audit (Studi Empiris pada BPKP Perwakilan Provinsi Bali)". Jurnal Buletin Studi Ekonomi 21(2): 115-127.

Wijaya, N. 2016. "Faktor-faktor Yang Mempengaruhi Kualitas Audit". Jurnal Bisnis Dan Akuntansi 18(2): 187-192.

Yendrawati, R. 2006. "Analisis Hubungan Antara Profesionalisme Auditor Dengan Pertimbangan Tingkat Materialitas Dalam Proses Pengauditan Laporan Keuangan.” Jurnal Akuntansi dan Investasi 7(2): 219-42. 